\title{
Changes of attitudes towards inclusion in the physical education after experiencing the educational programme Paralympic school day
}

\author{
Jakub Řičica, Ladislav Baloun, Ondřej Ješina, \\ Ilona Pavlová, Martin Kudláček
}

\begin{abstract}
The aim of the study is to find out to what extent do the cognitive attitudes of selected primary and lower secondary school pupils towards pupils with disabilities and attitudes to the inclusive physical education (PE) change after they experience the educational programme Paralympic school day (PSD).

In total, 78 pupils (37 boys and 41 girls) aged from 9 to 14 (mean age 12.72 \pm 1.22 ) participated in the research. In order to perform the presented research, the questionnaires CAIPECZ (attitudes towards the inclusive PE) and ACL (cognitive attitudes towards people with disabilities) were used. The change in the pupils' attitudes was assessed in the span of three weeks (before and after they experienced PSD). From the results of the performed study, it may be concluded that when the pupils went through PSD, they statistically significantly improved $p<0,001$ in the area of cognitive attitudes at the small effect size coefficient $(r=0,32)$. However, the attitudes towards a model pupil with disabilities did not prove a statistically significant change $(p=0.27)$ at the effect size coefficient $r=0.09$.
\end{abstract}


Key words: adapted physical activities, adapted physical education, adolescent, special education needs.

\title{
Vliv vzdělávacího programu Paralympijský školní den na postoje spolužáků $\mathrm{k}$ žákům $\mathrm{s}$ tělesným postižením
}

\begin{abstract}
Abstrakt
Cílem studie je zjistit k jaké změně kognitivních postojů k osobám s tělesným postižením (TP) a postojům k inkluzivní tělesné výchově (TV) dojde po absolvování vzdělávacího programu Paralympijský školní den (PŠD) u žáků na vybraných základních školách.

Výzkumu se zúčastnilo 78 žáků a to 37 chlapců a 41 dívek ve věku 9 až 14 let (průměr $12,72 \pm 1,22$ ). Pro provedení této studie byly použity dotazníky CAIPE-CZ (postoje k inkluzivní TV) a ACL (kognitivní postoje k osobám s TP). Změna postojů byla posuzována v časovém rozmezí tří týdnů (před a po absolvování PŠD). Z výsledku provedené studie vyplývá, že po absolvování PŠD došlo ke statisticky významnému zlepšení $p<0,001$ v oblasti kognitivních postojů při koeficientu effect size na malém účinku $(r=0,32)$. Výsledky postojů k modelovému žákovi s tělesným postižením neprokázaly statisticky významnou změnu $(p=0,27)$ při koeficientu effect size $r=0,09$.
\end{abstract}

Klíčová slova: inkluze, tělesná výchova, aplikované pohybové aktivity, vzdělávání.

DOI: $10.5507 /$ epd.2021.016

\section{Introduction}

In terms of education, by the term inclusion, we mean the placement of pupils with special educational needs (SEN) into a regular school together with their peers (Kroupová et al., 2016). According to Sherrill (2004), teachers should strive to make those pupils be accepted within the class even though some of them are handicapped which makes them somehow different when compared with classmates without disabilities. The studies (e.g. Armstrong, Morris, Abraham, \& Tarrant, 2017; Goodwin \& Watkinson, 2000; Yun $\&$ Beamer, 2018) prove that SEN pupils who attend a regular school are often perceived as 'different'. This is one of the reasons why the SEN pupils are more frequently bullied comparing to their peers without disabilities (Farmer et al., 2012). No similar research has been conducted in Czech Republic, according to available research papers. Therefore, these conclusions are based on research from abroad. Panagiotou, Evaggelinou, Doulkeridou, Mouratidou and Koidou (2008) state that an inclusive school is a place where everyone belongs, they are accepted and supported by their peers and other 
members of school community to make their educational needs be met. Additionally, this means to provide all pupils a suitable educational programme in a framework of inclusive education. This educational programme should be demanding, however, it should be oriented not only on their abilities and needs but also on any support by teachers' assistants (Lindsay \& Edwards, 2013). The inclusive education trend led to the increased number of studies focusing on the discovery of attitudes towards the SEN pupils (mainly towards pupils with disabilities). Boer, Pijl and Munnaert (2012) discovered that pupils in general assume a neutral attitude towards their SEN peers. As Ješina mentions, PE is, as a general subject, intended to all pupils, including the SEN pupils. Because of this fact, PE becomes inclusive PE by the presence of an integrated pupil (Ješina et al., 2020).

Ješina et al. (2020) defines the inclusion as a process of educational reaction, and the creation of conditions for as wide common participation in the educational process (and later in one's life) as possible. The inclusion of SEN pupils into lesson of PE at schools is, however, rather specific. First, it is necessary to take the current pupil's health state into account together with the type and degree of their disability, and their individual abilities and possibilities. The educational support, motivation and creativity of teachers play a principal role. Apart from that, the adjustments of gyms and purchases of special sports and compensating equipment should be mentioned as well as the alteration of rules of individual sports and games. For the inclusive $\mathrm{PE}$, it is necessary to create the best possible environment and teaching staff - however, the lack of professional readiness of PE teachers to work with SEN pupils is presently common (Kudláček \& Ješina, 2013).

PE at schools is a specific subject which is also connected to the issue of attitudes when including all pupils, even those with special educational needs. One of the methods of how to work on the improve the level of attitudes towards and acceptance of SEN pupils into the educational process is the educational programme called Paralympic school day (PSD). This is an educational programme which was created by International Paralympic Committee and its aim is to make primary and lower secondary school pupils aware and understand people with disabilities. Promotion of sport (physical activities) and awareness of sport of people with disabilities belong among main principles of the programme. The content of individual PSD programme is, however, adjusted according to conditions at individual schools - the content depends on the number and age of the pupils, material and mainly spatial conditions of the school and their specific wishes. The following activities which are included in the PSD are the most frequently performed; a theoretical lecture on the sport of people with disabilities, meeting with a para-sportsperson, basic mobility without visual control, Boccia and Goalball (Ješina, Kudláček, \& Migdauová, 2017).

The results of studies which researched the influence of inclusive PE on pupils without disabilities attitudes differ - e. g. some pupils evince improvement and they showed more positive attitudes or a change of their behaviour towards their SEN classmates 
after they experienced PSD (Obrusníková, Válková, \& Block, 2003). Striving to describe the life of people with disabilities, a study was created in which the pupils tried to imitate the handicap of their SEN classmates. When doing so, pupils without disabilities simulated various types of disability by specific activities and model situations. The results of this study showed that the pupils who experienced the programme evinced positive attitude towards SEN classmates (Loovis \& Loovis, 1997). On the other hand, other studies indicate that the majority of pupils have negative attitude towards the inclusion of their classmates with disabilities into the lessons of PE despite the fact that they took part in an intervention programme (Ellery \& Rauschenbach, 2000). Several research studies dealing with the influence of the educational programme Paralympic school day on the children's attitudes towards the SEN classmates were performed worldwide (e.g. Panagiotou et al., 2008; Hutzler \& Levi, 2008; Reina, López, Jimenez, Garcia-Calvo, \& Hutzler, 2011; McKay, Block, \& Park, 2015). In the Czech Republic alone, the influence of PSD programme on the attitudes was researched by Ješina et al. (2006), Xafopoulos, Kudláček and Evaggelinou (2009), and Liu, Kudláček and Ješina (2010).

The aim of the presented study is to find out to what extent do the cognitive attitudes of selected primary and lower secondary school pupils towards pupils with disabilities and attitudes to the inclusive physical education (PE) change after they experience the educational programme Paralympic school day (PSD).

\section{Methodology}

\section{Participants}

The research sample comprised of selected pupils from three schools based in Prague. In total, 78 pupils ( 37 boys and 41 girls) aged from 9 to 14 (mean age 12.72 \pm 1.22 ) participated in the research. From the school no. 1, 35 pupils ( 21 girls and 14 boys) from the 2 nd grade of lower secondary school took part in the study. From the school no. 2, 35 pupils ( 17 girls and 18 boys) from the 2 nd grade of lower secondary school took part in the study. From the school no. 3, 8 pupils ( 3 girls and 5 boys) from the 5 th grade of primary school took part in the study. The mentioned pupils, however, were not a part of a class in which a pupil with disability was included. That means that they have neither any experience with inclusive PE nor with inclusive education. The selection of the research sample was intentional (temporal and local). The participants signed an informing consent. This study was approved by the Ethics Committee of the Faculty of Physical Culture, Palacký University Olomouc (no. 42/2018). 


\section{Data collection methods}

In the study, we used two data collection methods. To discover general cognitive attitudes towards people with disabilities, Adjective Checklist (ACL) was used. To discover attitudes towards inclusive PR Children's Attitudes Toward Integrated Physical Education questionnaire (CAIPE-CZ) was used. The questionnaire distribution and data collection were performed in a paper form.

\section{$\mathrm{ACL}$}

In the framework of this study, ACL (Siperstein, 2006) questionnaire was used; this questionnaire is based on the expression of pupils' cognitive attitudes in connection to their relation to their SEN classmates. The pupils were asked to describe a model handicapped classmate named Petr using characteristics stated before. By circling, the pupils could select any number out of 34 adjectives: one half was positive adjectives (intelligent, kind, clever, ...) and the other half was negative adjectives (stupid, evil, silly, ...).

$A C L$ was evaluated by adding adjectives and then adding the constant 20 . The score may take a value from 4 to 36 ; in case the final score is 20 or higher, it shows that the attitude towards pupils with disabilities is positive, the score lower than 20 shows a negative attitude towards them (Siperstein, 2006).

\section{CAIPE-CZ}

The questionnaire CAIPE-CZ was translated from English into Czech (Kudláček, Ješina, \& Wittmanová, 2011) and reviewed afterwards. The pupils were introduced to their imaginary classmate Petr before they filled in the questionnaire. Petr was described in the following fashion: Petr is the same age as you are. Because he cannot walk, he uses a wheelchair. He likes to play the same games as you do, however, he is not play them as well as you do. Despite the fact that he is able to move thanks to his wheelchair, he is slower than you are, and he would become tired faster than you. He is able to throw a ball but not that far as you can. He can catch the ball if it flies directly on him. He can serve during a volleyball game, but he is not able to serve from the back line. He is not able to shoot the ball as high to make a goal during a basketball game. Because he is not able use his legs, he cannot kick the ball.

After the description of Petr, pupil with disabilities, a series of question follows.

The questionnaire comprises of three parts: the first part contains three basic questions (sex, prior experience with people with disabilities, and the level of competitiveness. The second part contains eight questions focused on general attitudes towards inclusive PE (while the first two questions serve to make the respondents understand the Likert scale); the third part was dealing with the modification of sport rules. For the purposes of this study, the authors assessed the second and third part of the questionnaire (questions 1-13) together. 
The questionnaire is based on the four-level Likert scale $(4=$ yes, $3=$ rather yes, $2=$ rather no, $1=$ no). By adding the values from the questions $3-13$, the total score of the questionnaire is calculated.

\section{Intervention - Paralympic school day}

Paralympic school day (PSD) is an educational project of which the aim is to inform children about the issue of Paralympic sport and about the life of people with disabilities (mainly with a physical, visual, or mental disability). An additional aim of this project is a better acceptance of SEN pupil within a class (in case the pupil attends a school). At the same time, this enlightening programme strives to make a positive change of peers' attitudes towards people with disabilities. The target category for the PSD is pupils between 8 and 15 years of age. With minor modifications, younger and older pupils may also take part adequately in this programme as well as SEN pupils.

For the purposes of the presented study, PSD was performed at each school to the extent of 5 lessons. More specifically, it included the following activities: a) meeting with a Czech parasportswoman Tereza Diepoldová; b) wheelchair basketball; c) spatial orientation - patches and canes; d) boccia; e) goalball (one whole lesson - 45 minutes was dedicated to each of the activities).

\section{Data collection}

For the purposes of the present study, the data were collected at three schools based in Prague via questionnaires in form of repeated measuring. The first (pre-test) was carried out the day before PSD, the second one (post-test) was carried out 3 weeks after PSD intervention.

Data were collected in April and May 2019.

\section{Statistical analysis}

The authors used the SPSS 22.0 software (IBM Corp., Armonk, NY, USA) to statistically process the data while the Wilcoxon signed-rank test was used to compare the results. The level of statistical significance $a$ was set to a level $p=0,05$. The factual significance of the differences between the pre-test and post-test was calculated via 'effect size' coefficient of the Wilcoxon test:

$r=\frac{z}{\sqrt{N}}$,

in which $r$ means the value of the 'effect size' coefficient, $z$ is the value represented by the calculation of the Wilcoxon signed-rank test, and $\mathrm{N}$ is the total number of participants 
(Fritz, Morris, \& Richler, 2012). When evaluating the 'effect size' coefficient, the authors used norms stated in Fritz et al. (2012): $r>0.5$ is a large effect, $0.3<r \leq 0.5$ is a moderate effect, and $0.1<r \leq 0.3$ is a small effect.

\section{Results}

In accordance with the research methodology, it is possible to divide the results into two parts: results of $A C L$ questionnaire and results of CAIPE-CZ questionnaire. Because of the type of the data (ordinal measurements), the authors used a non-parametric test - therefore, the results were presented by the median value, minimal and maximal values, and quartiles 25 and 75 (without using the average values).

The ACL questionnaire results (which are presented in Table 1 and Figure 1) show that during the first measurement, the median value was 26 , the lower quartile was 22 and the upper quartile was 30. During the second measurement (after the intervention), the median value was 28 , the lower quartile was 24 and the upper quartile was 31 . After the second measurement, a statistically significant improvement $p<0.001$ in the final score was recorded. The value of effect size coefficient was $r=0.32$ - it is a small effect, according to Fritz et al. (2012).

The CAIPE-CZ questionnaire results (which are presented in Table 1 and Figure 2) show that during the first measurement, the median value was 27 , the lower quartile was 24 and the upper quartile was 29. During the second measurement (after the intervention), the median value was 26 , the lower quartile was 24 and the upper quartile was 30 . After the second measurement, a slight worsening in the final score was recorded, however, it was not statistically significant $(p=0.27)$ at the effect size $r=0.09$.

\section{Table 1}

Descriptives statistics and results of Wilcoxon paired test $(\mathrm{N}=78)$

\begin{tabular}{|c|c|c|c|c|c|c|c|c|c|c|c|c|}
\hline \multirow{2}{*}{ škála } & \multicolumn{5}{|c|}{ PRE-TEST } & \multicolumn{5}{|c|}{ POST-TEST } & \multirow{2}{*}{$p(W)$} & \\
\hline & Medián & Min & Max & Q25 & Q75 & Medián & Min & Max & Q25 & Q75 & & \\
\hline $\mathrm{ACL}$ & 26.00 & 17.00 & 36.00 & 22.00 & 30.00 & 28.00 & 13.00 & 42.00 & 24.00 & 31.00 & $<0.001$ & 0.32 \\
\hline CAIPE & 27.00 & 18.00 & 51.00 & 24.00 & 29.00 & 26.00 & 16.00 & 45.00 & 24.00 & 30.00 & 0.27 & 0.09 \\
\hline
\end{tabular}

Note: $M i n=$ minimum achieved score of the questionnaire; $M a x=$ maximum achieved score of the questionnaire; $Q 25=$ value in the lower quartile; $Q 75=$ value in upper quartile; $p(W)=p$ value of Wilcoxon test; $r=$ value of the coefficient effect size. 
Figure 1

Comparison of scores from Adjective Checklist questionnaire

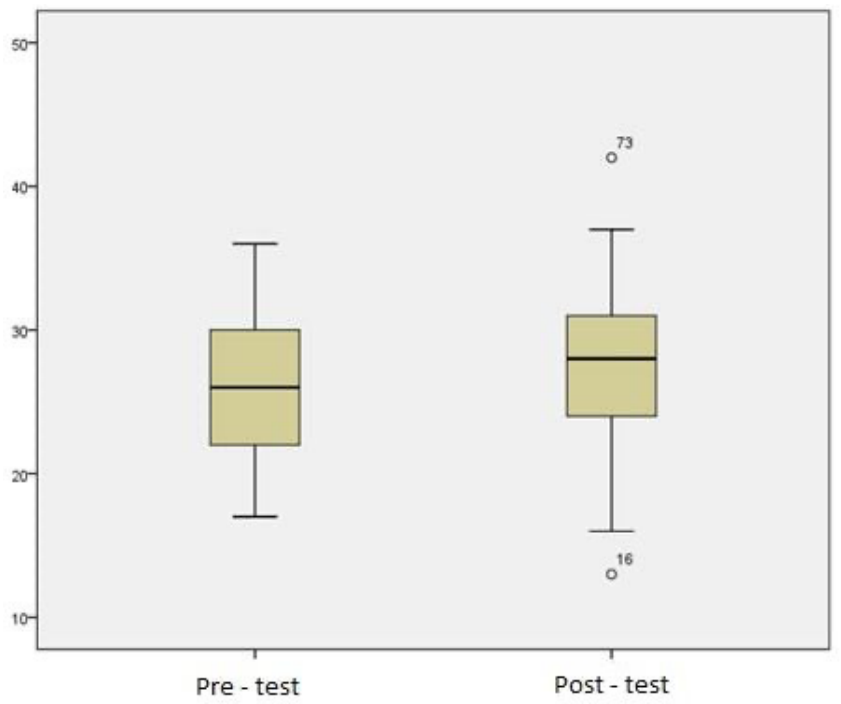

Figure 2

Comparison of scores from CAIPE-CZ questionnaire

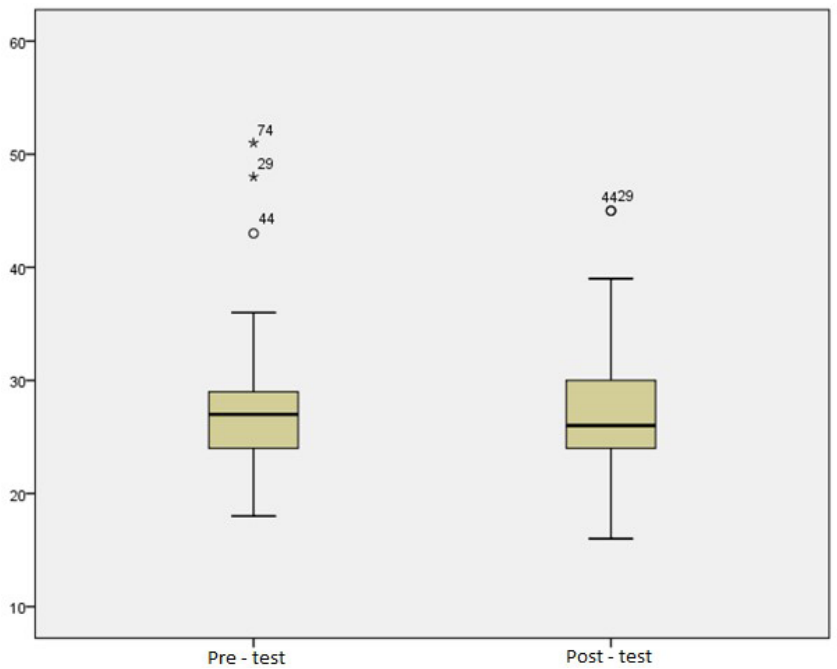




\section{Discussion}

The aim of the presented study is to find out to what extent do the cognitive attitudes of selected primary and lower secondary school pupils towards pupils with disabilities and attitudes to the inclusive physical education (PE) change after they experience the educational programme Paralympic school day (PSD).

Based on the research results, it is possible to state that a positive statistically significant change in the area of cognitive attitudes pupils with disabilities at the small effect size coefficient happens among the pupils after they experienced the educational programme PSD. However, the attitudes towards the inclusive PE and modification of sports' rules did not statistically significantly change after experiencing the PSD programme.

Similar results were discovered also in the framework of study by Xafopoulos et al. (2009) in which general cognitive attitudes among girls statistically significantly improved $(p=0.02)$; however, a statistically significant change among the attitudes towards the inclusive PE was not showed. Liu et al. (2010) discovered that a positive change of attitudes towards the inclusive PE was recorded after experiencing PSD, however, worse results were recorded in a part of a questionnaire dealing with the modifications of sport activities. No change of attitudes was recorded. McKay et al. (2015) performed a research using an experimental and a control group. The experimental group experienced PSD. The results showed statistically significant changes of attitudes towards the inclusive PE after the pupils experienced the intervention $p=0.002$. According to DePauw and Doll-Tepper (2000) and Hutzler, Jaakov, Almosny and Bergman (2001), the attitudes towards classmates with disabilities gradually change for the better in the framework of inclusive PE. More SEN pupils are getting included in the lessons of PE worldwide thanks to that. Hutzler et al. (2001) point out that there is a lot of countries where there is a governing method which serves to include more SEN pupils into common classes. Kippers and Bouramas (2003) and Christopoulou (2004) confirmed that programmes that include information and discussions dealing with disability and group and inclusive games may play a significant role in the process of change their attitudes, mainly among pupils without disabilities. The positive results (when researching the change of attitudes towards the SEN pupils in the framework of PSD) were confirmed also by the study by Van Biesen, Busciglio and Vanlandewijck (2006).

Kalyvas and Reid (2003) discovered that pupils did not agree with the modifications of rules of sport games when including SEN pupils into PE lessons. They mentioned lesser motivation as the main reason. Pupils without disabilities wanted their SEN peers to participate in PE lessons, however, they did not want them as teammates. The authors attribute this to the desire to win. Therefore, it is necessary to put more emphasis on the fun aspect of the game than to its competitive nature. Additionally, results of two more studies (Van Biesen et al., 2006; Ješina et al., 2006) showed negative sport-specific 
attitudes towards the inclusion of SEN pupils in the lessons of PE among pupils without disabilities. This was supported also by the results of the presented study in which there was no positive change of attitudes towards the modification of sport games rules (where the model handicapped pupil has an advantage compared to the other players) among pupils even after they experienced the educational programme PSD.

After they experienced one PSD, Greek pupils evinced a positive change of attitudes. Thanks to that, it was possible to reduce the incidents of problems connected to the inclusion of their SEN classmates into the PE lessons (Panagiotou et al., 2008). It is necessary to teach children without disabilities that their SEN classmates have a right to participate in PE lessons and other sport activities. Armstrong et al. (2017) proved in their study that the contact with people with disabilities may be an efficient method which leads to the improvement of pupils' attitudes towards their SEN classmates. The extended contact and direct contact with those people are seen as the most effective methods. This is partially proved by the positive change of cognitive attitudes towards pupils with disabilities in our research. An integral part of the performed PSD educational programme was also the meeting with para-sportswoman (a Paralympic games medallist) on the topic of sport and life of people with disabilities. At the same time, the results confirm the generally valid Allport contact hypothesis from 1954 (Allport, 2004) which confirms the positive effect of intergroup contact occur in contact situations characterized by four key conditions: equal status, intergroup cooperation, common goals, and support by social and institutional authorities.

As to why the pupils' attitudes remained unchanged regarding inclusive physical education, the assumption is that the questions were focused on modifying the rules of the game (basketball), so that the pupil with disabilities can participate in the class. Classmates without disabilities could have felt that the pupil with disabilities is being favoured. For this reason, most students did not have a positive attitude.

To list some limits of the presented study, it is necessary to state the fact that there was no control group. Therefore, it is not possible to deduce causal conclusions from the results.

Another limit of the presented study is the fact that the probands were selected intentionally. Another limit of the presented study is the fact that the participants were not split on the basis of gender, the education programme PSD is generally implemented for the whole group with no regard to gender.

The subsequent studies may measure the attitudes of one sample multiple times it would be a measurement within a longer period. The first measurement would be performed before the PSD intervention, the second one 3 weeks after PSD intervention, and the last (third) measurement would be performed 6 months after PSD. By doing so, it would be possible to find out whether there is a long-term sustainability of effect of PSD intervention. 


\section{Conclusion}

In conclusion, it is possible to state that after experiencing PSD intervention, a statistically significant positive change in terms of cognitive attitudes towards people with disabilities with a small effect size coefficient occurred among the pupils. On the other hand, no statistically significant change of attitudes towards the inclusive PE was recorded among the pupils.

\section{References}

Allport, G. W. (2004). O povaze předsudků (E. Geissler, Trans.). Praha: Prostor.

Armstrong, M., Morris, C., Abraham, C., \& Tarrant, M. (2017). Interventions utilising contact with people with disabilities to improve children's attitudes towards disability: A systematic review and meta-analysis. Disability and Health Journal, 10(1), 11-22.

Boer, A., Pijl, S., \& Minnaert, A. (2012). Students' attitudes towards peers with disabilities: A

review of the literature. International Journal of Disability Development and Education, 59, 379-392.

DePauw, K. P., \& Doll-Tepper, G. (2000). Toward progressive inclusion and acceptance: myth or reality? The inclusion debate and bandwagon discourse. Adapted Physical Activity Quarterly, $17(2), 135-143$.

Ellery, J. P., \& Rauschenbach, J. (2000). Impact of disability awareness activities on non disabled student attitudes toward integrated physical education with students who use wheelchairs. Research Quarterly for Exercise and Sport, 71(1), 99-106.

Farmer, T. W., Petrin, R., Brooks, D. S., Hamm, J. V., Lambert, K., \& Gravelle, M. (2012). Bullying involvement and the school adjustment of rural students with and witho disabilities. Journal of Emotional and Behavioral Disorders, 20, 19-37.

Fritz, C. O., Morris, P. E., \& Richler, J. J. (2012). Effect size estimates: Current use, calculation, and interpretation. Journal of Experimental Psychology: General, 141(1), 2-18.

Goodwin, D. L., \& Watkinson, E. J. (2000). Inclusive physical education from the perspective of students with physical disabilities. Adapted Physical Activity Quarterly, 17(2), 144-160.

Hutzler, Y., Yaakov, T., Almosny, Y., \& Bergman, U. (2001). Including children with physical disability in school and community: A textbook. Tel Aviv, Israel: The Mofet Institute for Research, Curriculum and Program Development for Teacher Educators (in Hebrew).

Hutzler, Y., \& Levi, I. (2008). Including children with disability in physical education: General and specific attitudes of high-school students. European Journal of Adapted Physical Activity, 1(2), 21-30.

Christopoulou, K. (2004). Attitudes towards the integration of children with disability: The influence of the Athens 2004 Paralympic education program, in application to primary school children. Unpublished Master Thesis, Departments of Physical Education and Sports Sciences of Aristotle University of Thessaloniki and Serres, Dimokritio University of Thrace and University of Thessaly. Greece.

Ješina, O., Lucas, S., Kudláček, M., Machová, I., \& Wittmannová, J. (2006). Effect of an intervention program on attitude of elementary school children toward inclusion of children with disability. Acta Facultatis Educationis Physicae, 37(1), 51-61.

Ješina, O., Kudláček, M., \& Migdauová, A. (2017). Vzdělávací program Paralympijský školní den. Tělesná výchova a sport mládeže, 83(6), 22-26. 
Ješina O. (2020). Otázky a odpovědi aplikované tělesné výchovy l, aneb, Inkluzivní tělesná výchova pro I. stupeň základních škol s přesahem do mateřských škol. Olomouc: Univerzita Palackého.

Kalyvas, V., \& Reid, G. (2003). Sport Adaptation, Participation, and Enjoyment of Students with and without Physical Disabilities. Adapted Physical Activity Quarterly, 20(2), 182-199.

Kippers, T., \& Bouramas, G. (2003). Attitudes toward integration of children with disabilities: The effect of the implementation of the paralympic education material "Athens 2004" on 5th and 6th grade primary school children in Hellas. Katholieke Universiteit, Leuven, Belgium.

Kroupová, K., Baše, L., Hanáková, A., Krahulcová, K., Martinková, E., Pastieriková, L., \& Vožechová, J. (2016). Slovník speciálně pedagogické terminologie: Vybrané pojmy. Praha: Grada.

Kudláček, M. Ješina, O. \& Wittmannová, J. (2011). Structure of a questionnaire on children's attitudes towards inclusive physical education (CAIPE-CZ) Acta Universitatis Palackianae Olomucensis. Gymnica, 41(4), 43-48.

Kudláček, M., \& Ješina, O. (2013). Integrovaná tělesná výchova, rekreace a sport. Olomouc: Univerzita Palackého.

Lindsay, S., \& Edwards, A. (2013). A systematic review of disability awareness interventions for children and youth. Disability and Rehabilitation, 35(8), 623-646.

Liu, Y., Kudláček, M., \& Ješina, O. (2010). The influence of Paralympic School Day on children's attitudes towards people with disabilities. Acta Universitatis Palackianae Olomucensis Gymnica, 40(2), 63-69.

Loovis, E. M., \& Loovis, C. L. (1997). A Disability Awareness Unit in Physical Education and Attitudes of Elementary School Students. Perceptual and Motor Skills, 84(3), 768-770.

McKay, C., Block, M., \& Park, J. Y. (2015). The Impact of Paralympic School Day on Student Attitudes Toward Inclusion in Physical Education. Adapted Physical Activity Quarterly: APAQ, 32(4), 331-348.

Obrusníková, I., Válková, H., \& Block, M. E. (2003). Impact of Inclusion in General Physical Education on Students Without Disabilities. Adapted Physical Activity Quarterly, 20(3), 230-245.

Panagiotou, A. K., Evaggelinou, C., Doulkeridou, A., Mouratidou, K., \& Koidou, E. (2008). Attitudes of 5 th and 6 th grade greek students toward the inclusion of children with disabilities in physical education classes after a Paralympic education program. European Journal of Adapted Physical Activity, 1(2), 31-43.

Reina, R., López, V., Jiménez, M., García-Calvo, T., \& Hutzler, Y. (2011). Effects of awareness interventions on children's attitudes toward peers with a visual impairment. International Journal of Rehabilitation Research, 34(3), 243-248.

Sherrill, C. (2004). Adapted physical activity, recreation, and sport: Crossdisciplinary and lifespan. Boston: McGraw-Hill.

Siperstein, G. N. (2006). Adjective Checklist (ACL). In N. Salkind (Ed.), Encyclopedia of Measurement and Statistics (pp.12-13). Thousand Oaks, CA: Sage Publications.

Van Biesen, D., Busciglio, A., \& Vanlandewijck, Y. (2006). Attitudes towards the inclusion of children with disabilities: The effect of the implementation of A Paralympic School Day on Flemish elementary children. In Proceedings of the 8th European Conference of Adapted Physical Activity, Faculty of Physical Culture, Palacký University, Olomouc. Retrieved 2. 2. 2020 from: http://www.eufapa., upol.cz/www/EUCAPA2006/full/vanbiesen1.pdf.

Xafopoulos, G., Kudláček, M., \& Evaggelinou, C. (2009). Effect of the intervention program. Acta Gymnica, 39(4), 63-71.

Yun, J., \& Beamer, J. (2018). Promoting physical activity in adapted physical education. Journal of Physical Education, Recreation and Dance, 89(4), 7-13. 


\section{Contacts:}

Mgr. Jakub Řičica

Mgr. Ladislav Baloun, Ph.D.

Mgr. Ondřej Ješina, Ph.D.

prof. Mgr. Martin Kudláček, Ph.D.

Department of Adapted Physical Activities

Faculty of Physical Culture Palacký University Olomouc

třída Míru 117, 77111 Olomouc, Czech Republic

e-mail: jakub.ricica01@upol.cz, ladislav.baloun@upol.cz, ondrej.jesina@upol.cz,

martin.kudlacek@upol.cz

Mgr. Ilona Pavlová, MBA

Department of Adapted Physical Education and Sport Medicine

Faculty of Physical Education and Sport Charles University

José Martího 31, Prague 6, 16252 Czech Republic

e-mail: ipavlova@frtv.cuni.cz 